\title{
Population structure and mating encounter rates in a marine pelagic invertebrate, Firoloida desmarestia (Mollusca)
}

\author{
Elia Lemus-Santana, Laura Sanvicente-Añorve*, Miguel Alatorre-Mendieta, \\ César Flores-Coto
}

Universidad Nacional Autónoma de México, Instituto de Ciencias del Mar y Limnología, Circuito Exterior S/N, 04510 México, D.F., Mexico

\begin{abstract}
Vertical distribution, sex ratio, size structure and mate encounters of Firoloida desmarestia in the southern Gulf of Mexico were analyzed during 4 seasons (in February, May, August and November). A total of 395 individuals were collected with an opening-closing net at 5 levels of the $105 \mathrm{~m}$ upper water column. Results indicated that the species reproduces throughout the year, with a reproductive peak in May and a low reproductive period from August to February. Length measurements indicated that females (as long as $30 \mathrm{~mm}$ ) are larger than males $(18 \mathrm{~mm}$ ). Estimations of a 'spatial overlap' index showed a high overlap degree between sexes, suggesting that patterns in their vertical distribution are not a reproductive barrier. Sex ratio (F:M) at birth seemed to be 1:1, but during most of the year the adult sex ratio was dominated by females. We propose that larger dimensions and faster swimming speeds of females provide competitive advantages over males in searching for food and avoiding predators. Simulations of mate encounters indicated that values during the low reproductive season were low under turbulent and nonturbulent conditions $\left(<4.9\right.$ males $\mathrm{d}^{-1}$ female $\left.^{-1}\right)$, but enough to fertilize a high percentage of females. During the high reproductive season, encounters were as high as 17.2 males d $^{-1}$ female $^{-1}$ because the high density of adult population and the influence of wind-induced turbulence. We suggest that some biological features of females (seminal receptacle and exocrine gland) compensate for the low encounter rates. A conceptual model for the population dynamics of $F$. desmarestia is proposed.
\end{abstract}

KEY WORDS: Sex ratio - Size structure - Encounter rates - Spatial overlap - Wind-induced turbulence $\cdot$ Vertical distribution $\cdot$ Demographic model $\cdot$ Population dynamics

\section{INTRODUCTION}

Most planktonic organisms inhabit the upper ocean layer. This zone exhibits active air-sea exchanges: wind force, heating, cooling, rainfall and evaporation all have profound effects on its vertical structure (Cronin \& Sprintall 2001, Sprintall \& Cronin 2001). While the effect of wind stress is ultimately felt in the entire ocean, the most immediate impact occurs in the upper layer (Cronin \& Sprintall 2001). Wind forces propagate downward

${ }^{*}$ Corresponding author: lesa@unam.mx into the ocean and generate mixing and turbulence (Zhang \& Tian 2014). Wind-induced turbulence may influence planktonic populations with either favorable or deleterious consequences, depending on its magnitude (MacKenzie et al. 1994). For instance, the moderate velocities of small-scale turbulent flows increase encounter rates between predators and prey (Rothschild \& Osborn 1988, Dzierzbicka-Glowacka 2005, Sanvicente-Añorve et al. 2007) and between potential mates (Schmitt \& Seuront 2008). However, higher velocities may re-

(C) The authors 2015. Open Access under Creative Commons by Attribution Licence. Use, distribution and reproduction are unrestricted. Authors and original publication must be credited.

Publisher: Inter-Research · www.int-res.com 
duce feeding rates of zooplankters and also affect the type of captured prey (MacKenzie et al. 1994). Therefore, predator-prey and mating encounter rates are two of the major features in zooplankton population dynamics (Schmitt \& Seuront 2008). Size structure and sex ratio are useful parameters to describe the shift in the number and composition of individuals of a population over time (Yarrow 2009), and simulation models arise as essential tools for understanding the population dynamics of wildlife species (Carlotti et al. 2000).

Most studies concerning population dynamics within the plankton community refer to crustaceans (Carlotti \& Sciandra 1989, Twombly 1994, Reid et al. 2002, Fiksen \& Giske 1995, Kiørboe 2006, 2007, Kim et al. 2010), but to our knowledge, no other plankton groups have been studied. In this study, we focused our efforts on the population dynamics of a small pelagic mollusk, Firoloida desmarestia.

$F$. desmarestia is a holoplanktonic mollusk belonging to the family Pterotracheidae (Heteropoda). This species typically occurs in tropical and subtropical oceanic waters (Seapy et al. 2003). Its morphology shows adaptations to the pelagic life: a highly transparent, elongate and cylindrical body; absence of shell and operculum; gill branches projecting from the body; and a dorsal visceral mass located posterior to the ventral swimming fin (Owre 1964, Lalli \& Gilmer 1989). As all heteropod mollusks, F. desmarestia swims by rapid movements of its single swimming fin, which is held upward in the water column (Lalli \& Gilmer 1989). Furthermore, the species has well-developed eyes, indicating that it is a visual predator (Land 1982), and its principal food source is gelatinous zooplankton (Lalli \& Gilmer 1989). Major predators of F. desmarestia include fishes, other heteropod species and large zooplankton, such as siphonophores, medusae and phyllosome larvae (Lalli \& Gilmer 1989, Wang et al. 2014).

F. desmarestia is a gonochorist and a sexually dimorphic species. Males have a large penis, a tentacle aside each eye, a sucker on the swimming fin and a rudimentary tail. By contrast, females lack a tail and sucker, but a permanent egg filament is present at the end of the animal (van der Spoel 1972, Lalli \& Gilmer 1989). Females reach maturity at $10-40 \mathrm{~mm}$ length (Tesch 1949), but little is known about the species' reproductive season (Lemus-Santana et al. 2014).

The Gulf of Mexico is subject to strong seasonal variations in oceanic conditions related to changes in wind force. In the southern Gulf, 2 wind episodes can be recognized: a 'low energy' period (from April to August) characterized by easterly winds of 3.10 to $5.20 \mathrm{~m} \mathrm{~s}^{-1}$ monthly average speeds, and a 'high energy' period (from September to March) dominated by north winds of 6.40 to $8.10 \mathrm{~m} \mathrm{~s}^{-1}$ monthly average velocities. During this period, sporadic extreme wind storms (>18.8 $\left.\mathrm{m} \mathrm{s}^{-1}\right)$ called 'Nortes' may also occur (Anonymous 1999). In this study we provide a first attempt to understand the population dynamics of $F$. demarestia by analyzing its seasonal abundance per size class, sex ratio, spatial overlap between males and females, and encounter rates between mates in the water column under turbulent and non-turbulent conditions. This study was achieved from the analysis of more than 300 samples collected in the southern Gulf of Mexico at 5 levels of the water column during 4 months.

\section{MATERIALS AND METHODS}

\section{Sampling}

Biological samples came from 4 oceanographic cruises held in February, May, August and November 1995. Zooplankton collections were made in neritic waters of the southern Gulf of Mexico over a series of 28 oceanographic stations arranged in 5 transects located between 18 and $20^{\circ} \mathrm{N}$ and 91 and $95^{\circ} \mathrm{W}$ (Fig. 1). A total of 326 samples were collected during the day and night using a multiple openingclosing net equipped with $75 \mathrm{~cm}$ diameter and $505 \mu \mathrm{m}$ mesh size nets, and 5 depth intervals $(0-6$, 6-12, 12-18, 45-55, and 95-105 m) were sampled, depending on the bathymetry. These collections form part of a research project named 'Monitoring prerecruit estuarine-dependent species' conducted by the University of Mexico to survey fish and shrimp larvae in the upper layer influenced by continental water discharges; samples at depths greater than $45 \mathrm{~m}$ were taken as a complement. The estimation of the volume of water strained by the nets was made using flowmeters, and a CTD probe was employed for the measurement of salinity and temperature at each sampling station. All samples were preserved in $4 \%$ formalin-seawater solution buffered with borax. In the laboratory, all holoplanktonic mollusks were removed from the samples and specimens of $F$. desmarestia were identified, sexed, measured and counted under a stereoscope. The numerical abundance of males and females was standardized according to the volume of filtered water. Seasonal 


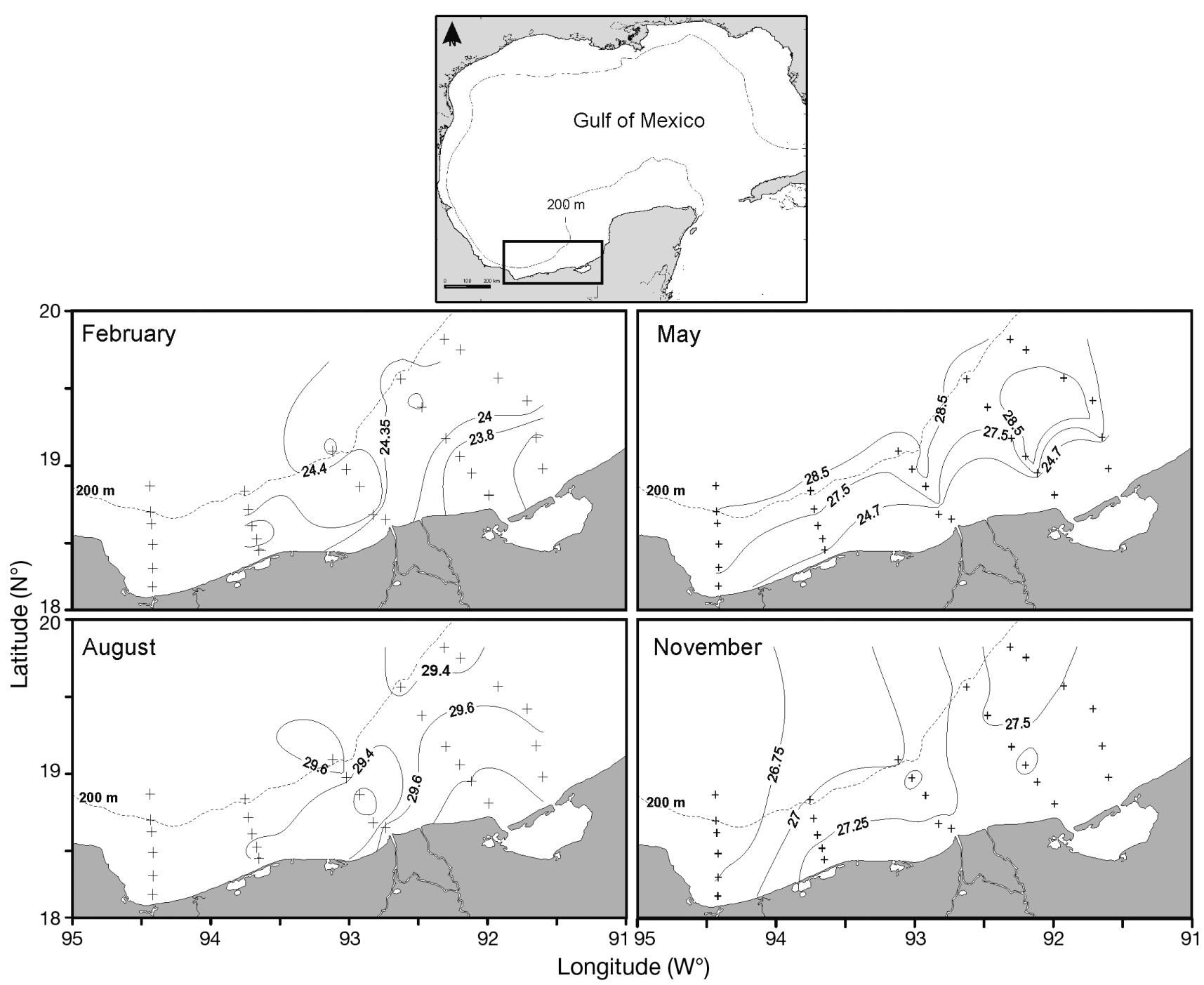

Fig. 1. Location of the study area, sampling stations $(+)$ and temperature conditions $\left({ }^{\circ} \mathrm{C}_{i}\right.$ solid contour lines) at the $10 \mathrm{~m}$ plane during February, May, August and November 1995 in the southern Gulf of Mexico

variation in the population densities was tested using the Kruskal-Wallis (K-W) test.

\section{Data analyses}

Encounter rates between males and females were estimated in accordance with 2 models, from Gerritsen \& Strickler (1977) and Rothschild \& Osborn (1988), which represent non-turbulent and turbulent conditions, respectively. These models originally described the encounter rate between predators and prey, but here we used them to estimate the encounter rate between mates.

The formulation of the Gerritsen and Strickler model is:

$$
C_{\mathrm{GS}}=\frac{\pi R^{2} N_{\mathrm{M}}}{6} \frac{\left(V_{\mathrm{m}}+V_{\mathrm{f}}\right)^{3}-\left|V_{\mathrm{m}}-V_{\mathrm{f}}\right|^{3}}{V_{\mathrm{m}} V_{\mathrm{f}}}
$$

where $C_{\mathrm{GS}}$ is the encounter rate by a single female in $1 \mathrm{~s}$ (males $\mathrm{s}^{-1}$ female $^{-1}$ ), $R$ is the encounter radius $(0.2 \mathrm{~m}), N_{\mathrm{M}}$ is the number of males per $\mathrm{m}^{3}$ at each stratum, $V_{\mathrm{m}}$ is the velocity of males $\left(\mathrm{m} \mathrm{s}^{-1}\right)$ and $V_{\mathrm{f}}$ is the velocity of females $\left(\mathrm{m} \mathrm{s}^{-1}\right)$.

The velocity of $F$. desmarestia specimens was taken to be between 0.2 and 2 body lengths (BL) $\mathrm{s}^{-1}$. Thus, for a F. desmarestia specimen of $20 \mathrm{~mm}$ length, the speeds varied between 0.004 and $0.04 \mathrm{~m} \mathrm{~s}^{-1}$. Speeds less than $2 \mathrm{BL} \mathrm{s}^{-1}$ are common in zooplankton organisms (Saiz 2009). The encounter radius $(R)$ represents the sphere of influence of the females and was assumed to be $20 \mathrm{~cm}$ due to the visual capa- 
bilities of F. desmarestia. A previous study (Hamner et al. 1975) indicated that heteropod species (Cardiapoda placenta) can attack prey located at distances of up to $60 \mathrm{~cm}$; therefore, an encounter radius of $20 \mathrm{~cm}$ is a conservative guess for the range of the visual perception.

The Rothschild and Osborn model $\left(C_{\mathrm{RO}}\right)$ considers the effect of turbulent velocities on the rate of encounter of mates. To introduce the effect of turbulent energy, Eq. (1) is modified as follows: $V_{\mathrm{m}}$ is replaced by $\left(V_{\mathrm{m}}^{2}+y^{2}\right)^{1 / 2}$ and $V_{\mathrm{f}}$ by $\left(V_{\mathrm{f}}^{2}+y^{2}\right)^{1 / 2}$ (Rothschild \& Osborn 1988). The term $y$ is the turbulent velocity and can be estimated as the rootmean-square of the turbulent kinetic energy $(k)$. The calculation of the terms $k$ and $y$ is fully explained in the Supplement at www.int-res.com/ articles/suppl/s001p163_supp.pdf, taking the mean monthly wind speeds $\left(U_{10}\right)$ as follows: $5,3.8,3.1$ and $6.1 \mathrm{~m} \mathrm{~s}^{-1}$ in February, May, August and November, respectively.

Estimations of the mating encounter rates were made in the upper 0-18 m layer, where adult specimens were more abundant and the turbulent velocities higher. Simulations were made for 2 specimens' velocities ( 0.2 and $2 \mathrm{BL} \mathrm{s}^{-1}$ ) and the 4 seasons. Results were expressed as the number of males encountered by a single female in a sphere of $20 \mathrm{~cm}$ radius (33.5 l) during $1 \mathrm{~d}$.

For each season, a 'spatial overlap' index $(O)$ was also calculated between mates. This index is defined by (Colwell \& Futuyma 1971):

$$
O=1-\frac{1}{2} \sum_{i=1}^{n}\left|\frac{N_{1 i}}{N_{1}}-\frac{N_{2 i}}{N_{2}}\right|
$$

where $N_{1 i}$ is the number of females in sample $i, N_{2 i}$ is the number of males in sample $i, N_{1}$ is the total number of females, $N_{2}$ is the total number of males and $n$ is the number of samples. The values of $O$ range from 0 , in the case of the minimum spatial co-occurrence between males and females, to 1 , which indicates the maximum value of spatial overlap.

\section{RESULTS}

Temperature conditions in the $10 \mathrm{~m}$ plane were the lowest in February $\left(23-24^{\circ} \mathrm{C}\right)$. In May, the temperature increased to around $28^{\circ} \mathrm{C}$ and reached its highest values in August $\left(\sim 29.6^{\circ} \mathrm{C}\right)$. In November, the temperature decreased to $27^{\circ} \mathrm{C}$ (Fig. 1). Most of the time, the salinity remained within typical oceanic values (around 36 PSU), except for November, when values decreased to 34 PSU due to high continental water discharges caused by high precipitation.

A total of 395 individuals of Firoloida desmarestia were sorted from the 326 samples collected in neritic waters of the southern Gulf of Mexico. The application of the Kruskal-Wallis test to the F. desmarestia data of the 4 months indicated that population density in May was significantly higher $(\mathrm{K}-\mathrm{W}=38.2$, df $=$ $3, \mathrm{p}<0.05$ ) than in the remaining months (Table 1 ).

The distribution of males and females of this species was mainly over the eastern slope and the narrow part of the shelf in all seasons (Fig. 2).

The spatial overlap index applied to abundance data of both sexes showed the highest value $(O=$ $0.76)$ in February, followed by August $(O=0.72)$, May $(O=0.70)$ and November $(O=0.54)$.

Body length measurements ranged from 2.6 to $30 \mathrm{~mm}$ in females and from 2.4 to $18 \mathrm{~mm}$ in males. All individuals were assigned to 1 of 5 size classes, with the highest abundances in almost all size classes in May (Fig. 3). Also in that month, distribution of lengths over the water column showed that larger specimens mainly occurred in the 3 upper strata (0-18 m), whereas smallest individuals were mainly found in the 2 lower levels of the water column (45-55 and 95-105 m; Fig. 4). This finding is not influenced by the gap in the vertical sampling design. The smallest female carrying eggs was $4.3 \mathrm{~mm}$ in length (first size class; Fig. 5), and percentages of gravid females were 33, 75, 85 and $100 \%$ in the subsequent size classes (Table 2). In August, November and February, females were less abundant than in May, but almost all were visibly gravid.

Table 1. Mean density (no. per $\mathrm{m}^{3}$ ) of males and females of Firoloida desmarestia at 5 water column strata in the southern Gulf of Mexico

\begin{tabular}{|c|c|c|c|c|c|c|c|c|c|}
\hline \multirow[t]{2}{*}{ Stratum } & \multirow{2}{*}{$\begin{array}{c}\text { Depth } \\
\text { (m) }\end{array}$} & \multicolumn{2}{|c|}{ February } & \multicolumn{2}{|c|}{ May } & \multicolumn{2}{|c|}{ August } & \multicolumn{2}{|c|}{ November } \\
\hline & & Females & Males & Females & Males & Females & Males & Females & Males \\
\hline 1 & $0-6$ & 0.134 & 0.069 & 0.517 & 0.310 & 0.247 & 0.122 & 0.255 & 0.127 \\
\hline 2 & $6-12$ & 0.423 & 0.279 & 1.196 & 0.968 & 0.108 & 0.039 & 0.568 & 0.181 \\
\hline 3 & $12-18$ & 0.103 & 0.051 & 1.153 & 1.951 & 0.029 & 0.059 & 0.199 & 0.235 \\
\hline 4 & $45-55$ & 0.172 & 0.283 & 0.537 & 0.809 & 0 & 0 & 0.183 & 0.193 \\
\hline 5 & 95-105 & 0 & 0 & 0.346 & 0.120 & 0 & 0 & 0 & 0 \\
\hline
\end{tabular}



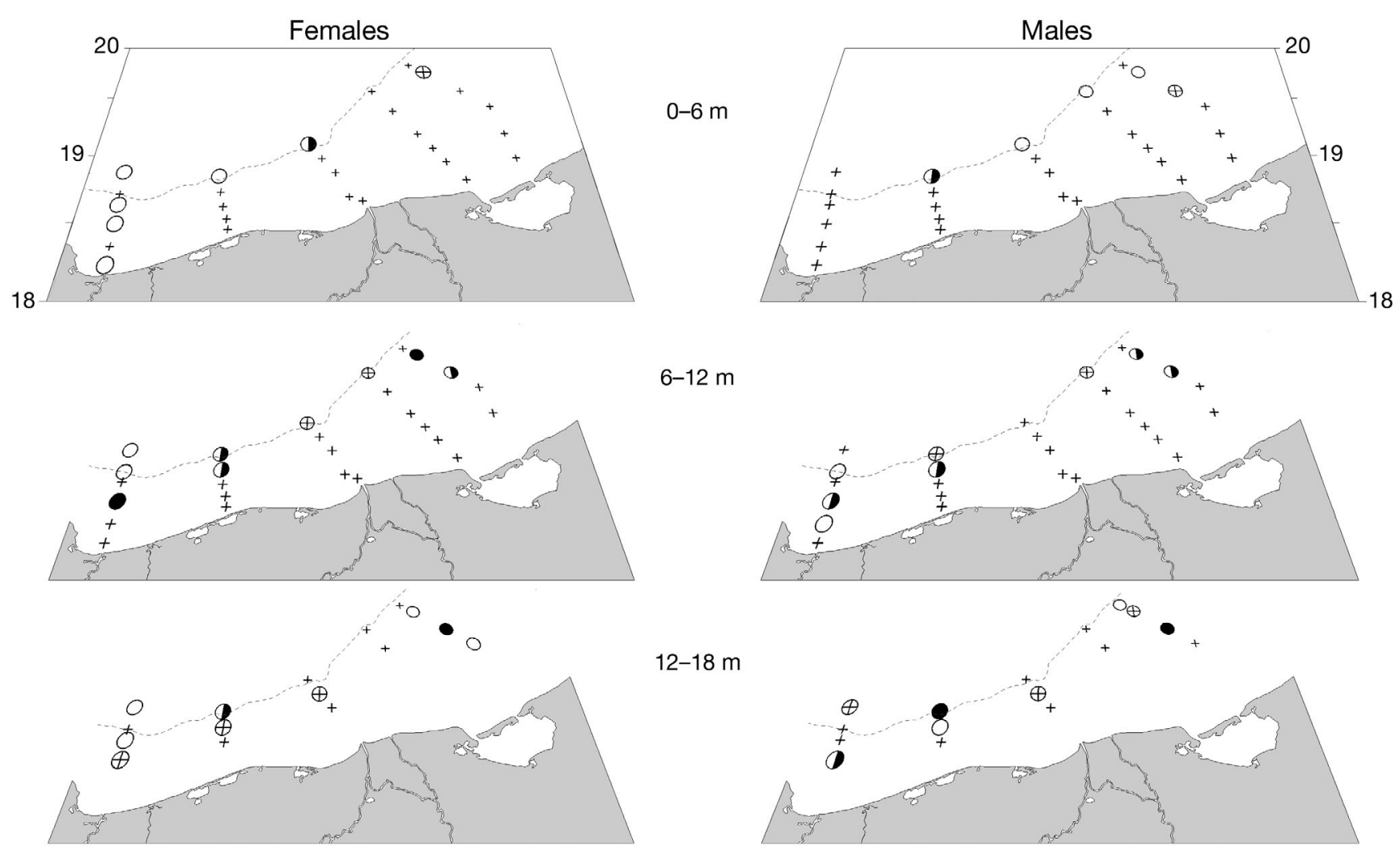

$12-18 \mathrm{~m}$
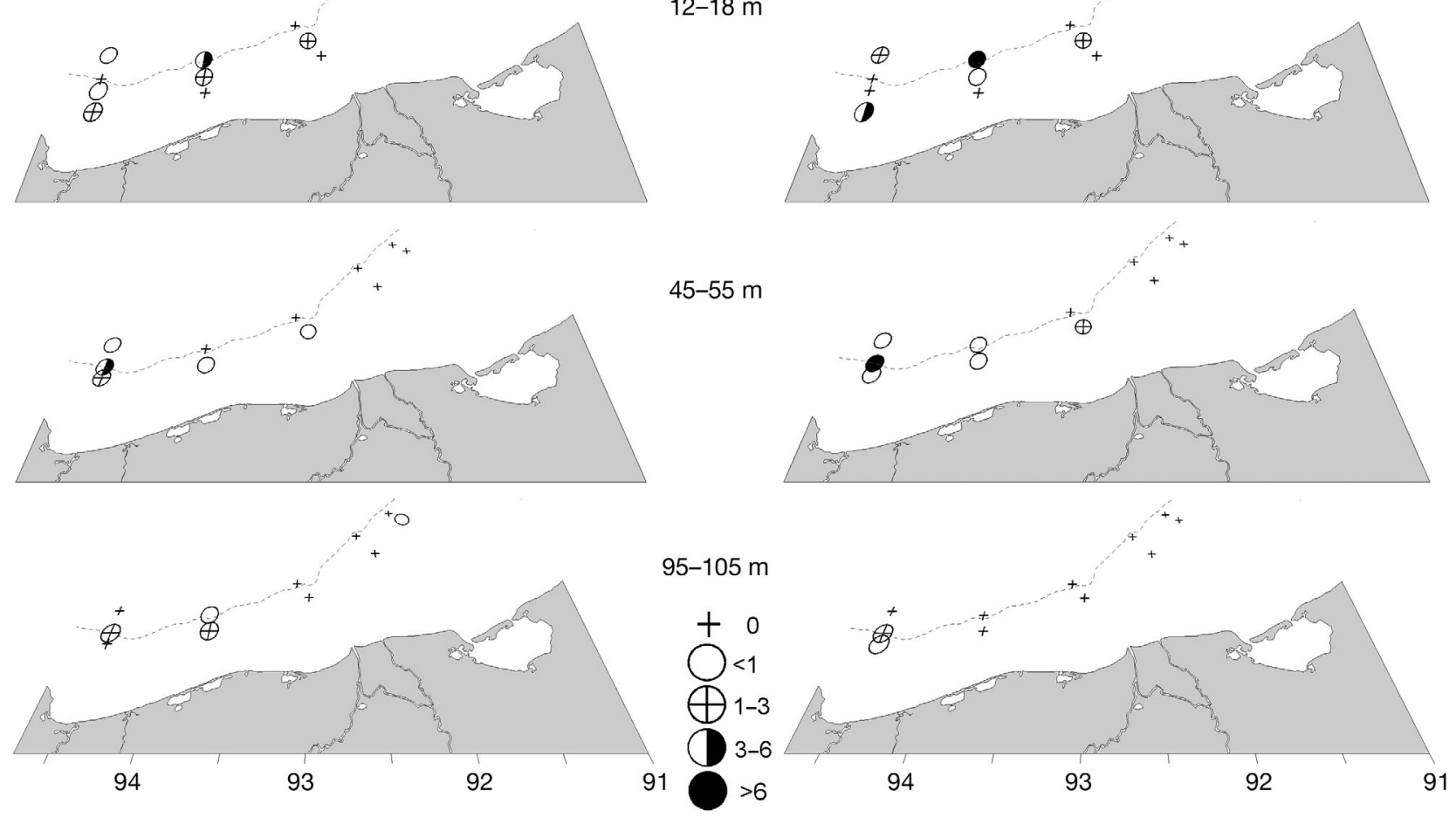

Fig. 2. Distribution of Firoloida desmarestia (number per $100 \mathrm{~m}^{3}$ ) at 5 levels of the water column in the southern Gulf of Mexico during May 1995

The overall sex ratios (F:M) were 1.6:1 in February, 1:1 in May, 1.9:1 in August, and 1.6:1 in November. The sex ratio in the smallest size class $(<6 \mathrm{~mm})$ was nearly 1:1 in May, whereas in November only 3 males were smaller than $6 \mathrm{~mm}$. No small individuals were collected in February and August, and no males at the highest size class $(>20 \mathrm{~mm})$ were recorded at any time (Table 2 ).
During the low reproductive season (August to February), encounter rates by a single female with males, under non-turbulent conditions, showed values lower than 1.5 males $^{-1}$ female $^{-1}$ for the analyzed range of swimming velocities (Fig. 6A). Considering the influence of the wind-induced turbulence, encounter rates increased to as high as 4.9 males d $^{-1}$ female $^{-1}$ in the second level of the water column in February (Fig. 7A). 


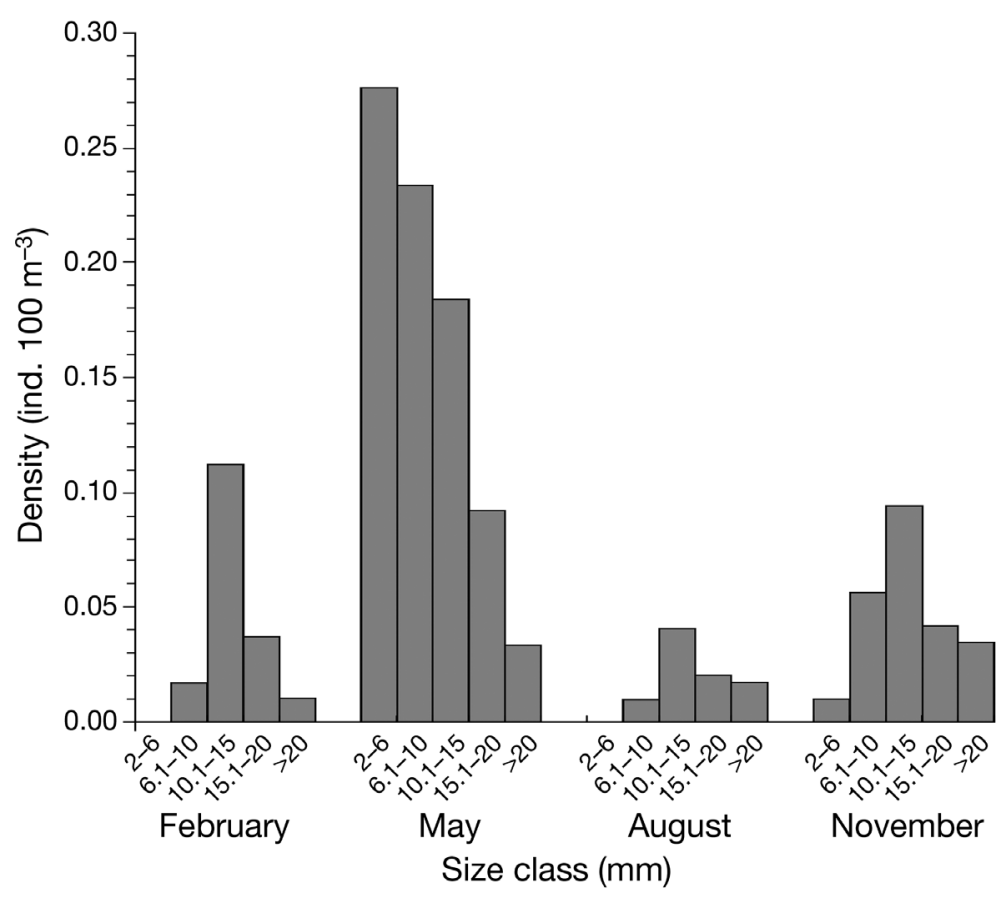

Fig. 3. Size structure of the Firoloida desmarestia population throughout 1 yr density in this stratum (Fig. 6B). When the wind blows, the highest estimated value was 17.2 males $^{-1}$ female $^{-1}$ (Fig. 7B).

\section{DISCUSSION}

\section{Distribution}

In the southern Gulf of Mexico, distribution of Firoloida desmarestia occurs in the slope region and on the narrow part of the shelf (Fig. 2), evidencing its oceanic origin. In accordance, Taylor \& Berner (1970) recorded this species in the oceanic province of the Gulf of Mexico, while van der Spoel (1996) considered the heteropod distribution as 'distant-neritic', a type of distribution similar to oceanic forms but controlled by gyres intermediate in size between those of the oceanic zone and small seas. Pafort-van Iersel (1983) mentioned that $F$. desmarestia has an extensive vertical distribution, from

During the high reproductive season (May) and under non-turbulent conditions, encounter rates reached maximum values in the third level of the water column (12-18 m) because of the high population surface waters to $870 \mathrm{~m}$ depth. In the present study, we analyzed the upper $105 \mathrm{~m}$ of the water column and observed that adults were mostly found in the upper level (0-18 m), whereas young specimens



Fig. 4. Box-plots of Firoloida desmarestia size values (mm) at different depths of the water column 


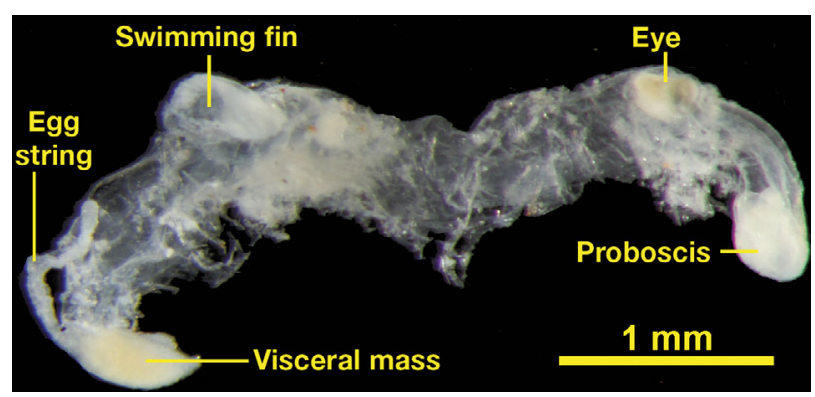

Fig. 5. A small Firoloida desmarestia specimen carrying eggs

were mainly found between 45 and $105 \mathrm{~m}$ (Fig. 4). We also found that the spatial overlap index was $>0.5$ in all months ( $O$ between 0.54 and 0.76 ) in all 4 seasons, suggesting the lack of a reproductive barrier due to a differential distribution of the sexes.

\section{Seasonality}

In the southern Gulf of Mexico, F. desmarestia was observed throughout the year with its highest abundance in May. It seems that warm spring temperatures in the study area trigger the reproductive process in holoplanktonic mollusks, as previously suggested by Xu \& Li (2005). In the Mediterranean Sea, previous results also show that the reproduction of 12 heteropod species is continuous throughout the year, with early and late veliger larvae collected during all months (Lalli \& Gilmer 1989). We propose that a reproductive advantage for the scarce $F$. desmarestia population is the presence of a seminal receptacle in females (Thiriot-Quiévreux 1973), which suggests that only one successful mate encounter is necessary to fertilize a female, similar to the spermathecae in some copepods (Kiørboe 2006). Moreover, numerous eggs in several stages of development have been observed in the egg filaments (Owre 1964), which supports the fact that reproduction of $F$. desmarestia is a continuous process. In the southern Gulf of Mexico, our findings indicate that the species reproduces throughout the year, with a long period of low reproductive rates and a peak in reproduction in May (Fig. 3).

\section{Size structure}

The smallest collected specimen was $1.4 \mathrm{~mm}$ length and the smallest sexually differentiated specimen was a male of $2.4 \mathrm{~mm}$ length. Owre (1964) found a newly metamorphosed larva (juvenile) of $1.2 \mathrm{~mm}$ body size. The comparison of these sizes suggests that the smallest specimens collected in this study are freshly metamorphosed animals and that sexual features appear at approximately $2.4 \mathrm{~mm}$ length. All size classes were well represented in May, the reproductive season (Fig. 3). Also, results showed that females attained larger sizes than males; in fact, the highest measures were $30 \mathrm{~mm}$ for females and $18 \mathrm{~mm}$ for males (Table 2). In the Mid North Atlantic Ocean, Pafort-van Iersel (1983) collected only 7 specimens of F. desmarestia (5 males and 2 females), recording the largest male at $19 \mathrm{~mm}$ and the largest female at $17 \mathrm{~mm}$. However, our analysis of almost 400 individuals indicated that females attain larger sizes than males. In a number of invertebrate species, males are approximately $50 \%$ smaller than females, a phenomenon called 'male dwarfism' (Hodgson 2009). As Tesch (1949) observed a female of $40 \mathrm{~mm}$ length, we suggest that males in $F$. desmarestia populations could be dwarf males. Tesch (1949) attributed the larger dimensions of specimens to the warmer water temperatures, and Pafort-van Iersel (1983) argued that development of animals in warm waters could be faster and sexual maturity may be reached at an earlier stage. In accordance, the present study recorded a gravid female at $4.3 \mathrm{~mm}$ length (Fig. 5); however, almost all females larger than $10.5 \mathrm{~mm}$ were gravid (Table 2). Accordingly, Tesch (1949) observed females with egg-strings mainly between 10 and $40 \mathrm{~mm}$ length.

Table 2. Size structure and sex ratio (F:M) of Firoloida desmarestia during 4 months in the southern Gulf of Mexico. Values in parentheses are the number of females carrying eggs

\begin{tabular}{|c|c|c|c|c|c|c|c|c|c|c|c|c|c|c|}
\hline \multirow{2}{*}{$\begin{array}{l}\text { Body size } \\
(\mathrm{mm})\end{array}$} & \multicolumn{3}{|c|}{-February } & \multicolumn{4}{|c|}{ May } & \multicolumn{3}{|c|}{${ }_{-}$August $\_$} & \multirow[b]{2}{*}{$\begin{array}{l}\text { Non- } \\
\text { sexed }\end{array}$} & \multicolumn{2}{|c|}{ - November- } & \multirow[b]{2}{*}{$\mathrm{F}: \mathrm{M}$} \\
\hline & Females & Males & $\mathrm{F}: \mathrm{M}$ & $\begin{array}{l}\text { Non- } \\
\text { sexed }\end{array}$ & Females & Males & $\mathrm{F}: \mathrm{M}$ & Females & Males & $\mathrm{F}: \mathrm{M}$ & & Females & Males & \\
\hline$<6$ & 0 & 0 & - & 10 & $29(1)$ & 32 & $1: 1.1$ & 0 & 0 & - & 2 & 0 & 3 & - \\
\hline $6.1-10$ & $3(1)$ & 1 & 3:1 & & $33(11)$ & 49 & $1: 1.5$ & 2 & 1 & $2: 1$ & & $8(6)$ & 11 & $1: 1.4$ \\
\hline $10.1-15$ & $16(12)$ & 11 & $1.4: 1$ & & $29(22)$ & 28 & $1: 1$ & 5 & 8 & 1:1.6 & & $21(21)$ & 12 & $1.8: 1$ \\
\hline $15.1-20$ & $5(5)$ & 4 & 1:1 & & $21(18)$ & 6 & $3.5: 1$ & $6(5)$ & 1 & $6: 1$ & & $11(10)$ & 3 & $3.6: 1$ \\
\hline$>20$ & $2(2)$ & 0 & - & & $7(7)$ & 0 & - & $6(6)$ & 0 & - & & $9(9)$ & 0 & - \\
\hline
\end{tabular}



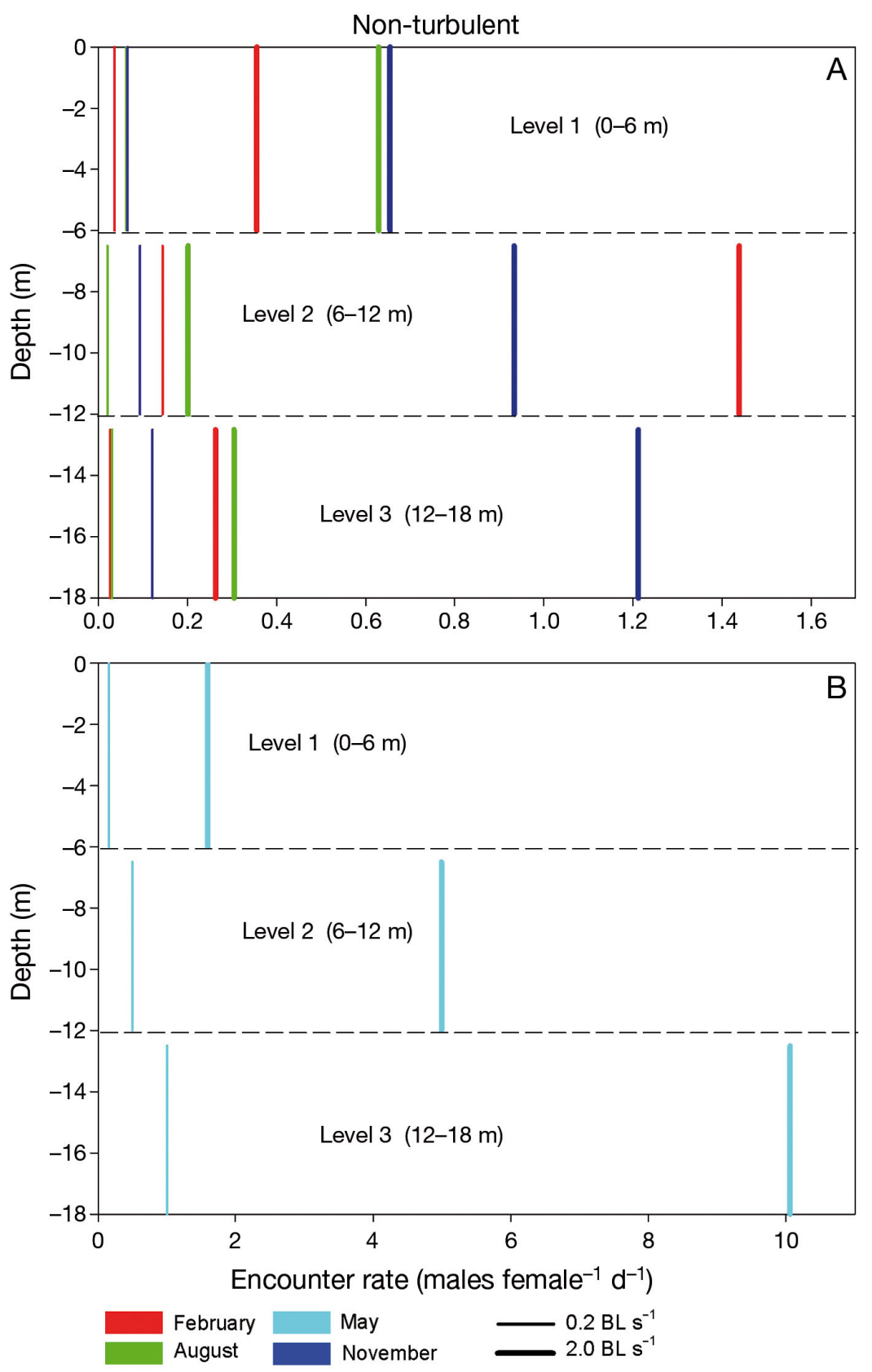

Fig. 6. Simulations of mate encounter profiles during (A) low and (B) high reproductive seasons of Firoloida desmarestia varying the specimens' velocity (body lengths [BL] s${ }^{-1}$ ) and under non-turbulent conditions ronmental conditions. Deviation from the 1:1 Fisherian proportion occurs because of environmental sex determination or sex-change factors, occurrence of endosymbionts (i.e. Wolbachia), sex-biased mortality or differences in physiological longevity (Werren 1997, Hodgson 2009, Gusmão et al. 2013). If equal sex ratios occur during the high reproductive season and skewed sex ratios exist during the low reproductive season, we propose that differences in physiological longevity (longevity free of predators) or survival rates between sexes may occur. In a number of terrestrial invertebrates and some copepod species, females have a higher life expectancy than males (Vollrath \& Parker 1992, Hirst et al. 2010). Regarding copepod populations, field observations and laboratory longevities suggest that higher mortality rates of males are mostly due to causes (predation, parasites, diseases) other than longevity (Hirst et al. 2010). For instance, in Oithona similis populations, predation mortality of males is high because their mate-finding behavior increases hydromechanical disturbance and encounters with predators (Hirst \& Ward 2008). In the family Euchaetidae, males have atrophied mouthparts that result in lower ingestion rates than females. Thus, difficulties while feeding may lead to a shorter life expectancy (physiological longevity) than that of females (Hirst et al. 2010). In the case of F. desmarestia populations, we think that females exhibit competitive advantages in searching for food or

\section{Sex ratio}

Sex ratio (F:M) at birth seems to be $1: 1$, as indicated by the smallest size class during the reproductive season (May; Table 2). When the entire population is considered, sex ratio was skewed towards females most of the year, except in May. Sex ratios are strongly influenced by genetic, ecological and envi- avoiding predators because of a higher swimming speed associated with their larger dimensions. In accordance, Lalli \& Gilmer (1989) stated that the larger heteropod specimens, which swim rapidly to approach prey quickly, probably evade their predators in the same way. However, mortality rates caused by physiological or predation effects are difficult to assess. 

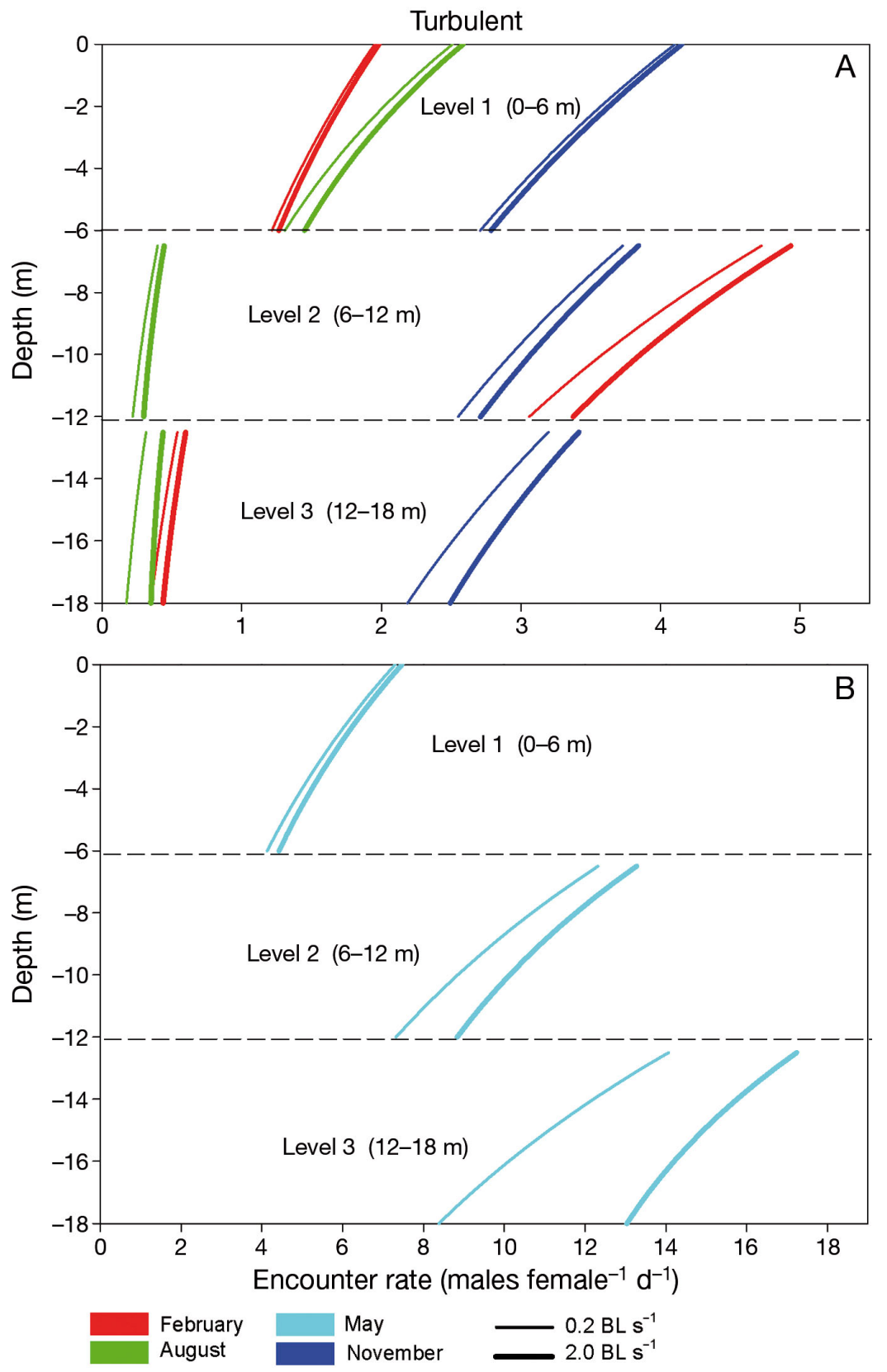

Fig. 7. Simulations of mate encounter profiles during (A) low and (B) high reproductive seasons of Firoloida desmarestia varying the specimens' velocity (body lengths $[\mathrm{BL}] \mathrm{s}^{-1}$ ) and under turbulent conditions

depend on the swimming speeds of males and females, their concentrations, and the effectiveness of remote male detection. The results of the present study revealed very low encounter rates under non-turbulent conditions (Fig. 6A). Three-dimensional video observations of planktonic copepods also revealed low mate encounter rates $\left(0.9\right.$ females $\mathrm{d}^{-1}$ male $^{-1}$ ) in a search volume of 4.41 (Kiørboe 2007). At surface waters, the turbulent environment induced encounter rates as high as 4.2 females $\mathrm{d}^{-1}$ male ${ }^{-1}$ in November, because the wind is strongest in this month (Fig. 7A). However, the highest encounter rates were observed in May due to the high population density (Fig. 7B). Considering the high percentage of fertilized females during the year (Table 2), it seems that the numbers of mate encounters are sufficient to maintain the $F$. desmarestia population throughout the year. As stated, the opportunity of a random encounter between mates is very low in low abundance populations. Thus, we propose that limited mating encounters in $F$. desmarestia may be compensated by some ecological adaptations. First, the presence of seminal receptacles in females (ThiriotQuiévreux 1973), which suggests that only one successful mating is required to fertilize a female (Kiørboe 2006). Second, the existence of well-developed eyes that are able to make scanning movements to detect surrounding organisms during the day and night (Land 1982), including mates. Third, the presence of an exocrine gland in females, whose function appears to be associated with the state of

\section{Encounter rates}

Heteropod populations are often low in density. Low population densities appear as a limitation on the encounter of mates (Kramer et al. 2011), but wind-induced turbulence can increase encounters among plankton specimens (Saiz et al. 2003, Sanvicente-Añorve et al. 2007, 2013). Further, Kiørboe \& Bagøien (2005) stated that mating encounter rates the reproductive system (Thiriot-Quiévreux 1973) and probably acts as a male attractor.

Based on the main results of this study, we are able to propose a demographic model of F. desmarestia population dynamics in the southern Gulf of Mexico (Fig. 8). The F. desmarestia population is small, but it reproduces throughout the year, showing a reproductive peak in the warm period of May. The sex ratio at birth seemed to be 1:1, but skewed towards females in 


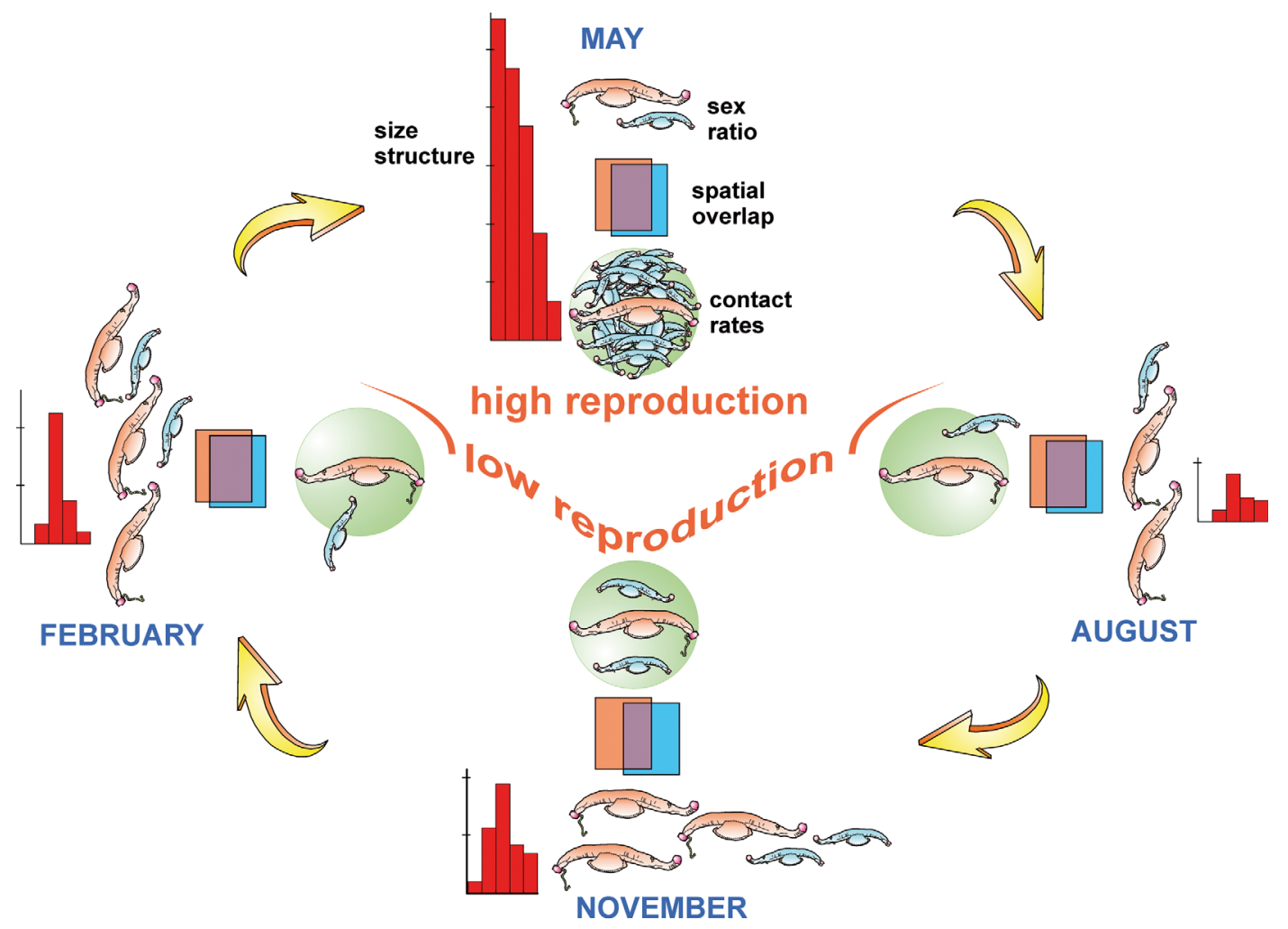

Fig. 8. A conceptual model of the population dynamics of Firoloida desmarestia in the southern Gulf of Mexico

the adult population. It seems that the larger size of females give them competitive advantages over males because high swim speeds enhance escape predator responses and increase their ability in searching for food. Spatial overlap between males and females is high (>0.50), suggesting that vertical distribution patterns of females and males are not a reproductive barrier. Mate encounters mostly take place in the upper layer of the water column because of higher population densities and more turbulent conditions. During the low reproductive season, encounter rates between mates are generally low, but are enough to fertilize a high number of adult females. During the high reproductive season (May), mate encounters were high due to the high density of adults as well as the influence of the wind-induced turbulence. We suggest that the well-developed eyes of $F$. desmarestia as well as the presence of a seminal receptacle and an exocrine gland in females are characteristics that enable the species to cope with low encounter rates.

Acknowledgements. The authors thank F. Zavala-García, K. Rubio-Sandoval and S. Aréstegui-Paz Rubio for their technical assistance during the development of this work, and Ana Isabel Bieler (Lab. Microcine, Fac. Ciencias, UNAM) for her kind help in taking the scientific photographs. The authors also express their gratitude to $M$. Reguero-Reza and the two anonymous reviewers for the useful comments on this manuscript.

\section{LITERATURE CITED}

Anonymous (1999) Estudios oceanográficos y meteorológicos en la Sonda de Campeche. Instituto Mexicano del Petróleo, Subdirección Técnica de Explotación, División de Estudios Especiales, México, D.F.

Carlotti F, Sciandra A (1989) Population dynamics model of Euterpina acutifrons (Copepoda: Harpacticoida) coupling individual growth and larval development. Mar Ecol Prog Ser 56:225-242

Carlotti F, Giske J, Werner F (2000) Modeling zooplankton dynamics. In: Harris $\mathrm{R}$, Wiebe $\mathrm{P}$, Lenz $\mathrm{J}$, Skjoldal HR, Huntley M (eds) ICES zooplankton methodology manual. Academic Press, San Diego, CA, p 571-667

Colwell RK, Futuyma DJ (1971) On the measurement of niche breadth and overlap. Ecology 52:567-576

Cronin M, Sprintall J (2001) Upper ocean structure: buoyancy and wind forcing. In: Steele $\mathrm{JH}_{\text {, Thorpe SA, }}$ Turekian KK (eds) Encyclopedia of ocean sciences. Academic Press, San Diego, CA, p 3219-3227

Dzierzbicka-Glowacka L (2005) Encounter rates in zooplankton. Pol J Environ Stud 15:243-257

Fiksen Ø, Giske J (1995) Vertical distribution and population dynamics of copepods by dynamic optimization. ICES J Mar Sci 52:483-503 
Gerritsen J, Strickler JR (1977) Encounter probabilities and community structure in zooplankton: a mathematical model. J Fish Res Board Can 34:73-82

Gusmão LFM, McKinnon AD, Richardson AJ (2013) No evidence of predation causing female-biased sex ratios in marine pelagic copepods. Mar Ecol Prog Ser 482: 279-298

> Hamner WM, Madin LP, Alldredge AL, Gilmer RW, Hamner PP (1975) Underwater observations of gelatinous zooplankton: sampling problems, feeding biology, and behavior. Limnol Oceanogr 20:907-917

> Hirst AG, Ward P (2008) Spring mortality of the cyclopoid copepod Oithona similis in polar waters. Mar Ecol Prog Ser 372:169-180

> Hirst AG, Bonnet D, Conway DVP, Kiørboe T (2010) Does predation control adult sex ratios on longevities in marine pelagic copepods? Limnol Oceanogr 55:2193-2206

Hodgson AN (2009) Reproduction and sex in invertebrates. In: da Silva AP (ed) Reproduction and development biology. Encyclopedia of Life Support System. Developed under the auspices of the UNESCO, EOLSS Publishers, Paris, available at http: //www.eolss.net, p 1-27

> Kim HS, Yamaguchi A, Ikeda T (2010) Population dynamics of the euphausiids Euphausia pacifica and Thysanoessa inspinata in the Oyashio region during 2007 spring phytoplankton bloom. Deep-Sea Res II 57:1727-1732

Kiørboe T (2006) Sex, sex-ratios, and the dynamics of pelagic copepod populations. Oecologia 148:40-50

Kiørboe T (2007) Mate finding, mating, and population dynamics in a planktonic copepod Oithona davisae: there are too few males. Limnol Oceanogr 52: 1511-1522

Kiørboe T, Bagøien E (2005) Motility patterns and mate encounter rates in planktonic copepods. Limnol Oceanogr 50:1999-2007

Kramer AM, Sarnelle O, Yen J (2011) The effect of mating behavior and temperature variation on critical population density of a freshwater copepod. Limnol Oceanogr 56:707-715

Lalli CM, Gilmer RW (1989) Pelagic snails. The biology of holoplanktonic gastropod mollusks. Stanford University Press, Stanford, CA

Land MF (1982) Scanning eye movements in a heteropod mollusk. J Exp Biol 96:427-430

Lemus-Santana E, Sanvicente-Añorve L, Hermoso-Salazar M, Flores-Coto C (2014) Holoplanktonic Mollusca from the southern Gulf of Mexico. Part 1: Heteropods. Cah Biol Mar 55:229-239

MacKenzie BR, Miller TJ, Cyr S, Leggett W (1994) Evidence for dome-shaped relationship between turbulence and larval fish ingestion rates. Limnol Oceanogr 39: 1790-1799

Owre HB (1964) Observations on development of the heteropod mollusks Pterotrachea hippocampus and Firoloida desmaresti. Bull Mar Sci Gulf Caribb 14: 529-538

Pafort-van Iersel T (1983) Distribution and variation of Carinariidae and Pterotracheidae (Heteropoda, Gastropoda) of the Amsterdam Mid North Atlantic Plankton Expedition 1980. Beaufortia 33:73-96

> Reid K, Murphy EJ, Loeb V, Hewitt RP (2002) Krill population dynamics in the Scotia Sea: variability in growth and mortality within a single population. J Mar Syst 36:1-10

Rothschild BJ, Osborn TR (1988) Small-scale turbulence and plankton contact rates. J Plankton Res 10:465-474
Saiz E (2009) Swimming dynamics of zooplankton. In: Duarte CM, Lot A (eds) Marine Ecology. Encyclopedia of Life Support System. Developed under the auspices of the UNESCO, EOLSS Publishers, Paris, available at www.eolss.net, p 1-25

Saiz E, Calbet A, Broglio E (2003) Effects of small-scale turbulence on copepods: the case of Oithona davisae. Limnol Oceanogr 48:1304-1311

Sanvicente-Añorve L, Alatorre MA, Flores-Coto C, Alba C (2007) Relationships between fish larvae and siphonophores in the water column: effect of wind-induced turbulence and thermocline depth. ICES J Mar Sci 64: 878-888

> Sanvicente-Añorve L, Lemus-Santana E, Flores-Coto C, Alatorre-Mendieta M (2013) Vertical segregation of holoplanktonic mollusks in the epipelagic layer, southern Gulf of Mexico. Helgol Mar Res 67:397-405

Schmitt FG, Seuront L (2008) Intermittent turbulence and copepod dynamics: increase in encounter rates through preferential concentration. J Mar Syst 70:263-272

Seapy R, Lalli CM, Wells FE (2003) Heteropoda from western Australia waters. In: Wells FE, Walker DI, Jones DS (eds) The marine flora and fauna of Dampier, Western Australia. Western Australian Museum, Perth, p 513-546

Sprintall J, Cronin MF (2001) Upper ocean vertical structure. In: Steele JH, Thorpe SA, Turekian KK (eds) Encyclopedia of ocean sciences. Academic Press, San Diego, CA, p 3120-3129

Taylor D, Berner L (1970) The heteropoda (Mollusca: Gastropoda). In: Pequegnat JC, Chace FA (eds) Contributions on the biology of the Gulf of Mexico. Texas A\&M University Oceanographic Studies 1, Gulf Publishing, Houston, TX, p 231-244

Tesch JJ (1949) Heteropoda. The Carlsberg Foundation's Oceanographical Expedition round the world 1928-30 and previous 'Dana' expeditions. Dana Report No. 34, Bianco Luno A/S, Copenhagen

Thiriot-Quiévreux C (1973) Heteropoda. Oceanogr Mar Biol Annu Rev 11:237-261

Twombly S (1994) Comparative demography and population dynamics of two coexisting copepods in a Venezuelan foodplain lake. Limnol Oceanogr 39:234-241

van der Spoel S (1972) Notes on the identification and speciation of Heteropoda (Gastropoda). Zool Meded 47: 545-560

van der Spoel S (1996) Heteropoda. In: Gasca R, Suárez E (eds) Introducción al estudio del zooplancton marino. ECOSUR-CONACYT, Chetumal, México, p 407-457

Vollrath F, Parker GA (1992) Sexual dimorphism and distorted sex ratios in spiders. Nature 360:156-159

> Wang M, O'Rorke R, Nodder SD, Jeffs AG (2014) Nutritional composition of potential zooplankton prey of the spiny lobster phyllosoma (Jasus edwardsii). Mar Freshw Res 65:337-349

> Werren JH (1997) Biology of Wolbachia. Annu Rev Entomol 42:587-609

Xu ZL, Li C (2005) Horizontal distribution and dominant species of heteropods in the East China Sea. J Plankton Res 27:373-382

Yarrow G (2009) The basics of population dynamics. Clemson University, Extension Forestry and Natural Resources, 29, Clemson

Zhang Y, Tian J (2014) Enhanced turbulent mixing induced by strong wind on the South China Sea shelf. Ocean Dyn 64:781-796 